\title{
Outcrossing Characteristics and Yield Potentiality of Restorer Line of Rice
}

\section{Md Nur Alam Siddique ${ }^{1 *}$, MA Khaleque Mian² and Umakanta Sarker ${ }^{2}$}

${ }^{1}$ MS Student, Department of Genetics and Plant Breeding, Bangabandhu Sheikh

Muzibur Rahman Agricultural University, Bangladesh

${ }^{2}$ Professor, Department of Genetics and Plant Breeding, Bangabandhu Sheikh

Muzibur Rahman Agricultural University, Bangladesh

*Corresponding Author: Md Nur Alam Siddique, MS Student, Department of

Genetics and Plant Breeding, Bangabandhu Sheikh Muzibur Rahman Agricultural

University, Bangladesh.
Received: December 22, 2020

Published: February 27, 2021

(C) All rights are reserved by Md Nur Alam

Siddique., et al.

\section{Abstract}

The present experiment was undertaken to study the statistical and genetic parameters, correlation coefficient, path coefficient of ten characters of restorer lines in rice and multivariate analysis of 18 characters of restorer lines in rice. Characters wise summaries were given below. Mean sum of square for anther length, anther breadth, pollen diameter, \% pollen sterility, duration of anthesis, number of panicles per hill, days to maturity, number of filled spikelet per panicle, \% spikelet sterility and grain yield per hill were highly significant due to genotypes in restorer line indicating wide range of variability among the restorer line for this traits. Low environmental effect and additive gene action were found in all these traits because $\sigma_{\mathrm{g}}^{2}$ and $\sigma_{\mathrm{p}}^{2}$ and the GCV and PCV were close to each other. Heritability, GA and GAPM was found high and moderate; all the traits indicate these traits will be effective for selection. High heritability, low GA and GAPM showed that both additive and environment influence of anther breadth, spikelet sterility percent and pollen diameter. Anther length showed significant positive correlation with anther breadth and significant negative correlation with duration of anthesis, number of filled spikelets per panicle and grain yield per hill both genotypic and phenotypic level and only significant positive genotypic correlation with pollen diameter and \% pollen sterility. Anther breadth showed significant positive genotypic and phenotypic correlation with \% pollen sterility and significant negative genotypic and phenotypic correlation with duration of anthesis and significant positive genotypic correlation with pollen diameter. Pollen diameter showed significant positive genotypic correlation with days to maturity and significant negative genotypic correlation with \% pollen sterility, duration of anthesis, number of panicles per hill, spikelet sterility percent and grain yield per hill. \% Pollen sterility showed significant positive $\sigma^{2}{ }_{g}$ and $\sigma^{2}{ }_{p}$ correlation with number of panicles per hill and significant negative $\sigma^{2}{ }_{p}$ correlation with duration of anthesis. Duration of anthesis showed significant positive $\sigma^{2}$ and $\sigma^{2}{ }_{p}$ correlation with days to maturity. Number of panicles per hill showed significant positive genotypic and phenotypic correlation with grain yield per hill and significant positive genotypic correlation with spikelet sterility percent. In case of genotypic correlation days to maturity showed positive correlation with number of filled spikelets per panicle and spikelet sterility percent, and showed positive phenotypic correlation with spikelet sterility percent. Number of filled spikelets per panicle showed significant positive genotypic and phenotypic correlation with spikelet sterility percent and grain yield per hill. Significant positive genotypic correlation was observed in between spikelet sterility percent and grain yield per hill. High positive direct effect on grain yield per hill was observed in case of number of filled spikelets per panicle and number of panicle per hill and similar lower effect in case of duration of anthesis, anther breadth and pollen diameter. I observed days to maturity, anther length and \% spikelet sterility had a direct negative effect on grain yield. Number of filled spikelets per panicle and number of panicles per hill was found as a main yield contribution character of the restorer line of rice because those characters have considerable $\sigma_{\mathrm{g}}^{2} \sigma_{\mathrm{p}}^{2} \mathrm{GCV}$ and PCV and others character.

Keywords: Anther Length; Anther Breadth; Diameter

Citation: Md Nur Alam Siddique., et al. "Outcrossing Characteristics and Yield Potentiality of Restorer Line of Rice". Acta Scientific Agriculture 5.3 (2021): $63-70$. 


\section{Introduction}

It clearly indicates that we have to increase our rice production because the demand for rice will increase in the next 30 years. Population will increase day by day at a rapid rate so we have to need millions of tons of extra food every year. Due to land scarcity for expansion of rice all the production must be higher. Increasing of rice production is not possible horizontally due to not availability of land so we can increase production of rice vertically. Hybrid rice seed production depends on the different flower characters of restorer (R) line and CMS (A) line. Outcrossing characters is very much important for effective hybrid rice seed production program. If outcrossing characteristics will good of a hybrid then seed production will be higher, as a result cost of hybrid rice seed will be low and finally production will be higher. CMS (A) line cross with restorer (R) line produced hybrid rice seed. Important characteristics of restorer $(\mathrm{R})$ line was high yield potentiality and good outcrossing character, if those character was present in a restorer (R) line then seed production rate will be higher and also productivity.
Therefore, the above study was conducted on following objectives:

- To identify component lines (R line) with desirable out crossing characteristics.

- To estimate the yield potentiality of restorer (R) line of rice.

- To study the genetic diversity among the restorer lines.

\section{Results and Discussion}

Statistical and genetic parameters

Analysis of variance, statistical and genetic parameters of outcrossing characteristics of different Restorer line of rice:

In case of anther length, anther breadth, pollen diameter, pollen sterility\%, duration of anthesis, number of panicles per hill, days to maturity, number of filled spikelets per panicle, spikelet sterility percent and grain yield per hill, mean sum of square were significant $1 \%$ level of significant for genotype in restorer line (Table 1) indicating existence of considerable difference for this trait. The maximum anther length was found $3366 \mu$ and the minimum was recorded $2305 \mu$ with mean value $2765 \mu$.

\begin{tabular}{|c|c|c|c|c|c|c|c|c|c|c|}
\hline Parameter & $\begin{array}{c}\text { Anther length } \\
(\mu)\end{array}$ & $\begin{array}{c}\text { Anther } \\
\text { breadth } \\
(\mu)\end{array}$ & $\begin{array}{c}\text { Pollen } \\
\text { diameter } \\
(\mu)\end{array}$ & $\begin{array}{c}\text { Pollen } \\
\text { sterility } \\
(\%)\end{array}$ & \begin{tabular}{|c|} 
Duration \\
of Anthesis \\
(hr:min)
\end{tabular} & $\begin{array}{c}\text { Number } \\
\text { of panicles } \\
\text { per hill }\end{array}$ & $\begin{array}{l}\text { Days to } \\
\text { maturity }\end{array}$ & $\begin{array}{c}\text { Number of } \\
\text { filled } \\
\text { spikelets } \\
\text { per panicle }\end{array}$ & $\begin{array}{l}\text { Spikelet } \\
\text { sterility } \\
\text { percent }\end{array}$ & $\begin{array}{l}\text { Grain yield } \\
\text { per hill (g) }\end{array}$ \\
\hline $\begin{array}{l}\text { Mean sum of } \\
\text { square }\end{array}$ & $206566.91^{* *}$ & $2309.61^{* *}$ & $26.71^{* *}$ & $99.76^{* *}$ & $1.51^{* *}$ & $37.78^{* *}$ & $371.28^{* *}$ & $714.38^{* *}$ & $16.76^{* *}$ & $297.21^{* *}$ \\
\hline Mean & 2765 & 418.80 & 42.98 & 9.35 & 1.24 & 18.09 & 159.70 & 102.30 & 24.79 & 44.49 \\
\hline Range & $2305-3366$ & $\begin{array}{c}397.70- \\
503.20\end{array}$ & $35.21-46.52$ & $\begin{array}{l}2.27- \\
23.33\end{array}$ & $0.40-2.30$ & $\begin{array}{l}13.40- \\
24.70\end{array}$ & $148-176$ & $86-140.20$ & $\begin{array}{l}21.12- \\
28.66\end{array}$ & $32.72-69.28$ \\
\hline$\sigma_{g}^{2}$ & 60980.11 & 565.66 & 6.97 & 32.27 & 0.50 & 11.41 & 114.24 & 212.94 & 3.44 & 92.27 \\
\hline$\sigma_{e}^{2}$ & 23624.62 & 612.83 & 5.80 & 2.94 & 0.02 & 3.55 & 28.57 & 75.54 & 6.43 & 20.40 \\
\hline$\sigma_{p}^{2}$ & 84604.72 & 1178.49 & 12.77 & 35.21 & 0.52 & 14.96 & 142.80 & 288.49 & 9.89 & 112.67 \\
\hline $\mathrm{h}^{2}{ }_{\mathrm{b}}$ & 72.08 & 48.00 & 54.56 & 91.66 & 96.27 & 76.27 & 80.00 & 73.81 & 34.89 & 81.89 \\
\hline GA (5\%) & 431.88 & 33.94 & 4.02 & 11.20 & 1.43 & 6.08 & 19.69 & 25.83 & 2.26 & 17.91 \\
\hline GAPM & 15.62 & 8.10 & 9.34 & 119.80 & 115.15 & 33.59 & 12.33 & 25.25 & 9.11 & 40.25 \\
\hline GA (1\%) & 553.47 & 43.50 & 2.01 & 14.36 & 1.83 & 7.79 & 25.24 & 33.10 & 2.89 & 22.95 \\
\hline GAPM & 20.02 & 10.39 & 5.34 & 153.53 & 147.57 & 43.04 & 15.80 & 32.36 & 11.67 & 51.59 \\
\hline GCV & 8.93 & 5.68 & 6.14 & 60.74 & 56.97 & 18.67 & 6.69 & 14.27 & 7.49 & 21.59 \\
\hline PCV & 10.52 & 8.20 & 8.31 & 63.45 & 58.07 & 21.38 & 7.48 & 16.60 & 12.67 & 23.86 \\
\hline ECV & 5.56 & 5.91 & 5.60 & 18.33 & 11.22 & 10.41 & 3.35 & 8.50 & 10.23 & 10.15 \\
\hline
\end{tabular}

Table 1: Determination of statistical and genetic parameters of outcrossing, yield and its related traits of different restorer line of rice. ${ }^{* *}=$ Significant at $1 \%$ level, $\sigma_{\mathrm{g}}^{2}=$ Genotypic variance, $\sigma_{\mathrm{e}}^{2}=$ Environmental variance, $\sigma_{\mathrm{p}}^{2}=$ Phenotypic variance, $\mathrm{h}^{2} \mathrm{~b}=\mathrm{Heritability}$ in broad sense, GA = Genetic advance, GAPM = Genetic advance in Percent Mean, GCV = Genotypic Coefficients of Variations, PCV = Phenotypic Coefficients of Variations and ECV = Environmental Coefficients of Variations. 
The maximum anther breadth was found $503.2 \mu$ and the minimum was recorded $397.7 \mu$ with mean value $418.8 \mu$. The maximum pollen diameter was found $46.52 \mu$ and the minimum was recorded $35.21 \mu$ with mean value $42.98 \mu$. The maximum pollen sterility was found $23.33 \%$ and the minimum was recorded $2.27 \%$ with mean value $9.35 \%$. The maximum duration of anthesis was found 2.30 (hr: $\mathrm{min}$ ) and the minimum was recorded 0.40 (hr: min) with mean value 1.24 (hr: min). The maximum panicles per hill were found 24.74 and the minimum was recorded 13.40 with mean value 18.09 . The maximum days to maturity were recorded 176 and the minimum was recorded 148 with mean value 159.7. The maximum number of filled spikelets per panicle was found 140.2 and the minimum was recorded 86 with mean value 102.3. The maximum spikelet sterility was found $28.66 \%$ and the minimum was recorded $21.12 \%$ with mean value $24.79 \%$. The maximum grain yield per hill was found $69.28 \mathrm{~g}$ and the minimum was recorded $32.72 \mathrm{~g}$ with mean value $44.49 \mathrm{~g}$. Data showed that the difference between $\sigma_{\mathrm{g}}^{2}$ and $\sigma_{\mathrm{p}}^{2}$, the GCV and PCV were minimum indicating genotypic effect in case of all parameters is high. Cooker., et al. (1994) and Sharma., et al. [1] found high GCV value for grain yield per plant. For most of the trait heritability was medium, GA and GAPM was average, so effective selection was done. Reddy., et al. [2] found similar results in rice. Heritability for anther breadth, pollen diameter and spikelets sterility percent was low together with considerable low GA and GAPM indicated that selection for this character would not be effective. Mehetre., et al. [3] reported similar results in rice.

\section{Correlation coefficient}

Yield is a polygenic trait being controlled by many individual genes. So I am selecting those traits which were directly or indirectly influencing yield. Improvement of different traits which is highly associated with yield, it automatically takes on other different correlated traits. Present study of different pairs of genotypic correlation coefficients and phenotypic correlation coefficients are submitted in table2. The results are discussed under the following heads.

Outcrossing, yield and its contributing traits of restorer lines of different characters of genotypic and phenotypic correlation coefficient were given below:

Anther length $(\mu)$ found to display highly significant positive relationships with anther breadth, pollen diameter, pollen sterility\%, duration of anthesis, number of filled spikelets per panicle and grain yield per hill at genotypic level and also grain yield per hill at phenotypic level so that the traits are governed by same gene by pleiotropic effect and simultaneous improvement would be effective. Significant positive correlation was found in between anther length with anther breadth $(\mu)$, duration of anthesis and number of filled spikelets per panicle at phenotypic level. The character reflected significant negative association with duration of anthesis and number of filled spikelets per panicle both at genotypic and phenotypic level and highly significant negative association with grain yield per hill both genotypically and phenotypically. It appeared from the results that increasing anther length $(\mu)$ caused the plant to produce lesser duration of anthesis, number of filled spikelets per panicle and grain yield per hill. Anther length $(\mu)$ also showed insignificant positive correlation with pollen diameter $(\mu)$, pollen sterility and spikelets sterility percent phenotypically and number of panicles per hill genotypically. This character showed insignificant negative correlation with days to maturity, number of panicles per hill at genotypic and days to maturity, spikelet sterility percent at phenotypic level. Significant positive relationship was found in between anther breadth and \% pollen sterility both genotypic and phenotypic level and pollen diameter $(\mu)$ at genotypic level. Highly significant positive association between anther breadth $(\mu)$ and pollen diameter $(\mu)$ and \% pollen sterility indicates that the traits are governed by same gene by pleiotropic effect and simultaneous improvement would be effective. It was observed that this character showed significant negative association with duration of anthesis at both levels. It appeared from the results that increasing anther breadth caused the plants to produce higher pollen diameter, sterility and reduce the duration of anthesis period. Anther breadth $(\mu)$ also showed insignificant negative correlation with number of panicles per hill, number of filled spikelets per panicle, spikelet sterility percent and grain yield per hill both genotypically and phenotypically. It also showed insignificant positive phenotypic correlation with pollen diameter $(\mu)$ and days to maturity at genotypic and phenotypic level. Insignificant association of these traits indicated that the association between these traits is largely influenced by environmental factors. The character showed highly significant negative relationship with \% pollen sterility, duration of anthesis, number of panicles per hill and grain yield per hill at genotypic level and significant negative genotypic correlation with spikelet sterility percent. It appeared from the results that increasing pollen diameter caused the plants to produce lesser percentage of pollen sterility, duration of anthesis and spikelet sterility percent, lesser panicles and grain yield per hill. Pollen diameter $(\mu)$ also showed insignificant negative correlation with \% pollen sterility, duration of anthesis, number of panicles per hill, days to maturity, number of filled spikelets per panicle, grain yield per hill and insignificant positive relation with spikelet sterility percent at phenotypic level. It also showed insignificant positive correlation with number of filled spikelets per panicle at genotypic 
level. Mehetre., et al. [3] reported similar results in rice. Pollen sterility $\%$ correlates with number of panicles per hill at both the level. This result revealed that with increasing the percentage of pollen sterility number of panicles per hill was also increased. It was observed that \% Pollen sterility showed meaningless positive association with days to maturity and meaningless negative association with number of filled spikelets per panicle, spikelet sterility percent and grain yield per hill both at genotypic and phenotypic level. This character represents significant negative correlation with duration of anthesis at genotypic level and insignificant negative association with duration of anthesis at phenotypic level. Ramesha., et al. (1998) found similar results in rice. Duration of anthesis and days to maturity correlates both at genotypic and phenotypic level. Highly significant positive association between duration of anthesis and days to maturity indicates that the traits are governed by additive gene effect and simultaneous improvement would be effective. It also observed meaningless positive correlation with number of panicles per hill, number of filled spikelets per panicle, grain yield per hill and meaningless negative correlation with spikelet sterility percent both at genotypic and phenotypic level. Babu [4] found similar results in rice. Panicles per hill and grain yield per hill correlates both at genotypic and phenotypic level, meaningful definitive correlation with spikelet sterility percent at genotypic level. This result expressed increasing panicles per hill would have increasing grain yield per hill. Again it is expressed that meaningless definitive correlation with spikelet sterility percent at phenotypic level. This character expressed insignificant negative correlation with days to maturity and number of filled spikelets per panicle at both level. Haque., et al. (1991) found similar results in rice. Meaninglful definitive association was found between days to maturity and number of filled spikelets per panicle at both the level. This result revealed that with more days to maturity would have more number of filled spikelets per panicle. It also showed meaningful definitive relation with spikelet sterility percent at genotypic level and meaningless definitive relation in phenotypic level. Meaningless negative consistency was observed between days to maturity and grain yield per hill at all the level. Haque., et al. (1991) found similar results in rice. Number of filled spikelets per panicle expressed highly meaningful positive consistency with spikelet sterility percent and grain yield per hill at all the level. This result revealed that with more number of filled spikelets per panicle would have more grain yield per hill. Haque., et al. (1991) found similar results in rice. The trait, spikelet sterility percent expressed very meaningful definitive consistency with grain yield per hill at genotypic and phenotypic level and meaningless definitive relation with grain yield per hill. Kumar., et al. [5] observed high positive correlation of grain yield with spikelet fertility.

\section{Path coefficient analysis}

Screening of genotypic correlation of outcrossing, yield and its related characters in restorer lines are expressed in table 3.

Anther length expressed the negative straight influence on grain yield per hill (-0.408). Anther length showed maximum positive indirect effect through anther breadth (0.240) followed by pollen diameter $(0.178)$, days to maturity $(0.039)$, spikelet sterility percent $(0.036), \%$ pollen sterility $(0.029)$ and number of panicles per hill (0.029). The negative transcendental influence of the traits on yield via number of filled spikelets per panicle $(-0.330)$ was the highest comparison by duration of anthesis $(-0.205)$ as at least formed significant negative association between anther length and grain yield. Anther breadth showed positive direct effect on grain yield (0.501). This character, however, showed positive indirect effect through pollen diameter (0.159), \% pollen sterility (0.056) and spikelet sterility percent (0.007). This character also showed negative indirect effect via duration of anthesis (-0.294), anther length (-0.195), days to maturity $(-0.174)$, number of panicles per hill $(-0.143)$ and number of filled spikelets per panicle $(-0.088)$ contributed to result total insignificant negative genotypic correlation with grain yield per hill (-0.170). Pollen diameter showed positively straight influence on grain yield per hill (0.273). This character, however, showed positive indirect effect through anther breadth (0.292), spikelet sterility percent (0.056) and number of filled spikelets per panicle (0.049). The negative indirect effect via number of panicles per hill $(-0.463)$ followed by anther length $(-0.266)$ days to maturity $(-0.253)$, duration of anthesis $(-0.231)$ and $\%$ pollen sterility $(-0.058)$ contributed to result highly significant negative genotypic correlation with grain yield per hill $(-0.600)$. Mehetre., et al. (1996) found similar results in rice. A positive direct effect was observed for pollen sterility \% on grain yield $(0.082)$. The indirect effect via anther breadth (0.344), number of panicles per hill (0.194) and spikelet sterility percent (0.028) was found to be positive. The negative high indirect effect via pollen diameter $(-0.195)$ followed by number of filled spikelets per panicle $(-0.188)$, duration of anthesis $(-0.150)$, anther length $(-0.146)$ and days to maturity $(-0.053)$ was contributed to result totally insignificant negative genotypic correlation with grain yield per hill (-0.085). Ramesha., et al. (1998) reported same results in rice. Satyavathi., et al. [6] found spikelet sterility had direct effect on yield. Duration of anthesis expressed the definitive straight influence on grain yield per hill (0.605). Duration of anthesis showed positive indirect effect through anther length $(0.138)$ followed by number of filled spikelets per panicle (0.089), number of panicles per hill (0.046) and spikelet sterility percent (0.040). But the 
negative indirect effect through days to maturity (-0.414), anther breadth $(-0.243)$, pollen diameter $(-0.104)$ and pollen sterility $(-0.020)$ finally made insignificant positive correlation between duration of anthesis and grain yield. A very definitive straight influence was observed by number of panicles per hill on grain yield (0.688). The indirect effect via number of filled spikelets per panicle $(-0.211)$ followed by pollen diameter $(-0.184)$, anther breadth $(-0.104)$, spikelet sterility percent $(-0.049)$ and anther length $(-0.017)$ was observed to be negative. But the direct effect of this trait and the positive indirect effect via days to maturity (0.192) followed by duration of anthesis (0.041) and pollen sterility (0.023). Padmavathi., et al. [7] found high definitive straight influence of number of panicles per plant on grain yield. A high negative direct effect was registered by days to maturity on grain yield $(-0.872)$. The indirect effect via number of filled spikelets per panicle (0.358) followed by duration of anthesis $(0.288)$, anther breadth $(0.100)$, pollen diameter $(0.079)$, anther length (0.018) and pollen sterility (0.005) was found to be positive. The negatory transcendental influence via number of panicles per hill $(-0.151)$ and spikelet sterility percent $(-0.048)$ was represent to result totally meaningless negative genotypic correlation with grain yield per hill $(-0.223)$. Number of filled spikelets per panicle had the highest definitive straight influence on grain yield per hill (0.872). This character also showed negative indirect effect through days to maturity (-0.358), spikelet sterility percent $(-0.172)$, number of panicles per hill $(-0.166)$, anther breadth $(-0.051)$ and pollen sterility $(-0.018)$. But positive indirect effect through anther length (0.155), duration of anthesis (0.062) and pollen diameter $(0.015)$ contributed to result significant positive genotypic correlation with grain yield per hill (0.329). Grain yield would be meaningfully higher by streight selection of genotypes based on this character. Awasthi., et al. (1998) found similar result for this trait. Spikelet sterility percent expressed negative straight influences on grain yield per hill $(-0.171)$. This character also showed negative indirect effect through days to maturity $(-0.245)$, duration of anthesis $(-0.140)$, pollen diameter $(-0.089)$ anther breadth $(-0.021)$ and pollen sterility $(-0.013)$. This character, however, showed positive indirect effect through number of filled spikelets per panicle (0.920), number of panicles per hill (0.198) and anther length (0.086). So, spikelet sterility percent represent to observed data highly meaningful definitive genotypic correlation with grain yield per hill (0.525). Padmavathi., et al. [7] reported spikelet sterility had definitive straight influence on grain yield [8-28].

\begin{tabular}{|c|c|c|c|c|c|c|c|c|c|c|}
\hline Parameters & & $\begin{array}{c}\text { Anther } \\
\text { breadth }(\mu)\end{array}$ & $\begin{array}{c}\text { Pollen } \\
\text { diameter } \\
(\mu)\end{array}$ & $\begin{array}{l}\text { Pollen } \\
\text { sterility } \\
\text { (\%) }\end{array}$ & $\begin{array}{c}\text { Duration } \\
\text { of anthesis } \\
\text { (hr:min) }\end{array}$ & $\begin{array}{c}\text { Number of } \\
\text { panicles } \\
\text { per hill }\end{array}$ & $\begin{array}{c}\text { Days to } \\
\text { maturity }\end{array}$ & $\begin{array}{c}\text { Number } \\
\text { of filled } \\
\text { spikelets per } \\
\text { panicle }\end{array}$ & $\begin{array}{l}\text { Spikelet } \\
\text { sterility } \\
\text { percent }\end{array}$ & $\begin{array}{c}\text { Grain yield per } \\
\text { hill (g) }\end{array}$ \\
\hline \multirow{2}{*}{$\begin{array}{l}\text { Anther length } \\
(\mu)\end{array}$} & $\mathrm{r}_{\mathrm{g}}$ & $0.479^{* *}$ & $0.651^{* *}$ & $0.357^{* *}$ & $-0.339^{* *}$ & 0.042 & -0.045 & $-0.379 * *$ & -0.212 & $-0.392^{* *}$ \\
\hline & $r_{p}$ & $0.327^{*}$ & 0.052 & 0.238 & $-0.279 *$ & -0.003 & -0.107 & $-0.292^{*}$ & 0.006 & $-0.361^{* *}$ \\
\hline \multirow{2}{*}{$\begin{array}{l}\text { Anther breadth } \\
(\mu)\end{array}$} & $r_{g}$ & & $0.583^{* *}$ & $0.685^{* *}$ & $-0.485^{* *}$ & -0.207 & 0.199 & -0.101 & -0.042 & -0.170 \\
\hline & $r_{p}$ & & 0.132 & $0.505^{* *}$ & $-0.327^{*}$ & -0.031 & 0.143 & -0.083 & -0.065 & -0.181 \\
\hline \multirow{2}{*}{$\begin{array}{l}\text { Pollen diameter } \\
(\mu)\end{array}$} & $r_{g}$ & & & $-0.712^{* *}$ & $-0.381^{* *}$ & $-0.673^{* *}$ & $0.291 *$ & 0.057 & $-0.326^{*}$ & $-0.600^{* *}$ \\
\hline & $r_{p}$ & & & -0.107 & -0.121 & -0.184 & -0.008 & -0.185 & 0.148 & -0.197 \\
\hline \multirow{2}{*}{$\begin{array}{l}\text { (\%) Pollen } \\
\text { sterility }\end{array}$} & $\mathrm{r}_{\mathrm{g}}$ & & & & $-0.248^{*}$ & $0.282^{*}$ & 0.061 & -0.216 & -0.165 & -0.085 \\
\hline & $r_{p}$ & & & & -0.245 & $0.260^{*}$ & 0.032 & -0.187 & -0.082 & -0.073 \\
\hline \multirow{2}{*}{$\begin{array}{l}\text { Duration of } \\
\text { anthesis } \\
\text { (hr:min) }\end{array}$} & $\mathrm{r}_{\mathrm{g}}$ & & & & & 0.067 & $0.475^{* *}$ & 0.102 & -0.231 & 0.136 \\
\hline & $r_{p}$ & & & & & 0.094 & $0.411^{* *}$ & 0.118 & -0.113 & 0.121 \\
\hline \multirow{2}{*}{$\begin{array}{l}\text { Number of } \\
\text { panicles per hill }\end{array}$} & $r_{g}$ & & & & & & -0.220 & -0.242 & $0.288^{*}$ & $0.378^{* *}$ \\
\hline & $r_{p}$ & & & & & & -0.213 & -0.131 & 0.173 & $0.389^{* *}$ \\
\hline \multirow{2}{*}{ Days to maturity } & $r_{g}$ & & & & & & & $0.411^{* *}$ & $0.281^{*}$ & -0.223 \\
\hline & $r_{p}$ & & & & & & & $0.331^{*}$ & 0.080 & -0.179 \\
\hline
\end{tabular}




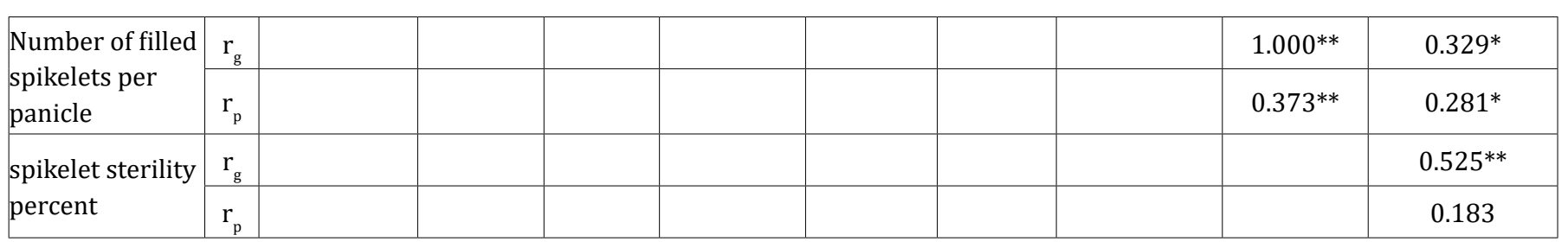

Table 2: Genotypic $\left(r_{g}\right)$ and phenotypic $\left(r_{p}\right)$ Correlation coefficient within outcrossing, yield and its related characters of different restorer line of rice.

* represent significant at $5 \%$ level of significance, ${ }^{* *}$ represent significant at $1 \%$ level of significance,

$r_{g}$ represent genotypic correlation coefficient and $r_{p}$ represent phenotypic correlation coefficient.

\begin{tabular}{|c|c|c|c|c|c|c|c|c|c|c|}
\hline Parameters & $\begin{array}{c}\text { Anther } \\
\text { length }(\mu)\end{array}$ & $\begin{array}{c}\text { Anther } \\
\text { breadth }(\mu)\end{array}$ & $\begin{array}{c}\text { Pollen } \\
\text { diameter } \\
(\mu)\end{array}$ & $\begin{array}{c}\text { Pollen } \\
\text { sterility } \\
(\%)\end{array}$ & $\begin{array}{c}\text { Duration } \\
\text { of anthesis } \\
\text { (hr:min) }\end{array}$ & $\begin{array}{c}\text { Number of } \\
\text { panicles } \\
\text { per hill }\end{array}$ & $\begin{array}{c}\text { Days to } \\
\text { maturity }\end{array}$ & $\begin{array}{c}\text { Number of } \\
\text { filled } \\
\text { spikelets } \\
\text { per panicle }\end{array}$ & $\begin{array}{l}\text { Spikelet } \\
\text { sterility } \\
\text { percent }\end{array}$ & $\begin{array}{c}\text { Grain } \\
\text { yield per } \\
\text { hill (g) }\end{array}$ \\
\hline Anther length $(\mu)$ & -0.408 & 0.240 & 0.178 & 0.029 & -0.205 & 0.029 & 0.039 & -0.330 & 0.036 & $-0.392^{* *}$ \\
\hline Anther breadth $(\mu)$ & -0.195 & 0.501 & 0.159 & 0.056 & -0.294 & -0.143 & -0.174 & -0.088 & 0.007 & -0.170 \\
\hline Pollen diameter $(\mu)$ & -0.266 & 0.292 & 0.273 & -0.058 & -0.231 & -0.463 & -0.253 & 0.049 & 0.056 & $-0.600^{* *}$ \\
\hline Pollen sterility (\%) & -0.146 & 0.344 & -0.195 & 0.082 & -0.150 & 0.194 & -0.053 & -0.188 & 0.028 & -0.085 \\
\hline $\begin{array}{l}\text { Duration of anthe- } \\
\text { sis (hr:min) }\end{array}$ & 0.138 & -0.243 & -0.104 & -0.020 & 0.605 & 0.046 & -0.414 & 0.089 & 0.040 & 0.136 \\
\hline $\begin{array}{l}\text { Number of panicles } \\
\text { per hill }\end{array}$ & -0.017 & -0.104 & -0.184 & 0.023 & 0.041 & 0.688 & 0.192 & -0.211 & -0.049 & $0.378^{* *}$ \\
\hline Days to maturity & 0.018 & 0.100 & 0.079 & 0.005 & 0.288 & -0.151 & -0.872 & 0.358 & -0.048 & -0.223 \\
\hline $\begin{array}{l}\text { Number of filled } \\
\text { spikelets per } \\
\text { panicle }\end{array}$ & 0.155 & -0.051 & 0.015 & -0.018 & 0.062 & -0.166 & -0.358 & 0.872 & -0.172 & $0.329^{*}$ \\
\hline $\begin{array}{l}\text { Spikelet sterility } \\
\text { percent }\end{array}$ & 0.086 & -0.021 & -0.089 & -0.013 & -0.140 & 0.198 & -0.245 & 0.920 & -0.171 & $0.525^{* *}$ \\
\hline
\end{tabular}

Table 3: Screening of genotypic correlation with grain yield into direct (bold) and indirect effect of outcrossing and yield granting characters in restorer line of rice.

* represent significant at $5 \%$ level of significance, ${ }^{* *}$ represent significant at $1 \%$ level of significance.

Residual effect, $\mathrm{R}=0.5952$

\section{Conclusion}

The $\sigma^{2}$ and $\sigma_{p}^{2}$ and the GCV and PCV were near for all the traits, indicating more genotypic influence for all the characters. High and moderate heritability with high and moderate genetic advance and genetic advance in percentage of mean observed for all the characters. But anther breadth, spikelet sterility percent and pollen diameter expressed considerable heritability with low GA and GAPM indicating advantage of both additive and environment influence for these traits. Anther length showed significant positive correlation with anther breadth and significant negative correlation with duration of anthesis, number of filled spikelets per pan- icle and grain yield per hill both genotypic and phenotypic level and only significant positive genotypic correlation with pollen diameter and \% pollen sterility. Anther breadth showed meaningful definitive genotypic and phenotypic relation with \% pollen sterility and significant negative genotypic and phenotypic correlation with duration of anthesis and significant definitive genotypic correlation with pollen diameter. Pollen diameter expressed meaningful definitive genotypic correlation with days to maturity and meaningful negative genotypic correlation with \% pollen sterility, duration of anthesis, number of panicles per hill, spikelet sterility percent and grain yield per hill. \% Pollen sterility expressed meaningful definitive genotypic and 
phenotypic correlation with number of panicles per hill and meaningful negative genotypic correlation with duration of anthesis. Duration of anthesis expressed meaningful definitive genotypic and phenotypic correlation with days to maturity. Number of panicles per hill expressed meaningful definitive genotypic and phenotypic correlation with grain yield per hill and meaningful definitive genotypic correlation with spikelet sterility percent. Days to maturity expressed meaningful definitive genotypic and phenotypic correlation with number of filled spikelets per panicle and meaningful definitive genotypic correlation with spikelet sterility percent. Number of filled spikelets per panicle expressed meaningful definitive genotypic and phenotypic correlation with spikelet sterility percent and grain yield per hill. Spikelet sterility percent expressed meaningful definitive genotypic correlation with grain yield per hill. Number of filled spikelets per panicle (0.872) and number of panicle per hill (0.688) expressed high definitive straight influence on grain yield per hill followed by duration of anthesis, anther breadth and pollen diameter. Days to maturity expressed the highest negative straight influence on grain yield. Anther length and \% spikelet sterility also expressed negative straight influence on grain yield. Considerable $\sigma_{\mathrm{g},}^{2} \sigma_{\mathrm{p}}^{2}$; considerable difference of GCV and PCV; high heritability with high GA and GAPM; significant $r_{g}$ and high direct effects were observed for number of filled spikelets per panicle and number of panicles per hill.

\section{Bibliography}

1. Sharma M K., et al. "Variability, heritabiHty, genetic advance, and genetic divergence in upland rice". International Rice Research Notes 21.1 (1996): 25-26.

2. Reddy J N., et al. "Variability and character association in lowland rice" (1997).

3. Mehetre S S., et al. "Variability, heritability, correlation, path analysis, and genetic divergence studies in M2 generation of gamma-irradiated upland rice". International Rice Research Notes 21 (1996): 2-3, 56-58.

4. Babu V R. "Study of genetic parameters, correlations and path coefficient analysis of rice (Oryza sativa L.) under saline conditions". Annals of Agricultural Research 17.4 (1997): 370-374.

5. Kumar G S., et al. "Studies on genetic variability, correlation and path analysis in rice during winter across the locations". Karnataka Journal of Agricultural Sciences 11.1 (1998): 73-77.

6. Satyavath C T., et al. "Variability, correlation and path analysis in rice varieties under different spacings". Indian Journal of Agricultural Research 35.2 (2001): 79-84.
7. Padmavathi N., et al. "Association of various yield components in rice (Oryza sativa L.)". Crop Research and Research on Crops 12.3 (1996): 353-357.

8. Anonymous. Krishi diary. Krishi tathy servic. Farmgate, Dhaka 1215 (2005): 23.

9. Cristo E., et al. "Evaluation of rice (Oryza sativa L.) hybrids and varieties". Cultivos-Tropicales 21.4 (2000): 51-53.

10. Dash S K., et al. "Association of quantitative traits and path analysis in medium land rice". Environment and Ecology 14.1 (1996): 99-102.

11. Durai A A. "Association analysis in hybrid rice". Annals of Agricultural Research 22.1 (2001): 137ᄀ-139.

12. Ibrahim S M., et al. "Multivariate analysis of genetic divergence over different environments in upland rice". Oryza 29 (1992): 137-138.

13. Iftekharuddaula K M., et al. "Genetic variability character association and path analysis of yield components in irrigated rice (Oryza sativa L.)". Bangladesh Journal of Plant Breeding and Genetics 14.2 (2001): 43-49.

14. Jager M I., et al. "Component of partial resistance of wheat seedlings to septoria nodorum". Euphytica 32 (1983): 575584.

15. Jha S K., et al. "Genetic divergence in wild rice germplasm of eastern U. P. India”. Oryza 36.20 (1999): 157-158.

16. Li Q L., et al. "Study on high yield breeding and genetic analysis of yield components of main rice cultivars in Jilin". 13.5 (1991): 3-6.

17. Luzi-Kihupi A. "Inter-relationship between yield and some selected agronomic characters in rice". African Crop Science Journal 6.3 (1998): 323-328.

18. Meenakshi. "Correlation and path analysis of yield and some physiological characters in rainfed rice". Oryza 36.2 (1999): 154-156.

19. Paul SK and A K Sarmah. "Interrelationship of yield and yield contributing characters in upland aus rice". Journal of the Saudi Society of Agricultural Sciences 10.2 (1997): 164-167.

20. Rao SA., et al. "Cause and effect relations of yield and yield components in rice (Oryza sativa L.)". Journal of Genetic, and Breed 51.1 (1997): 1-5. 
21. Reddy Y S and P V R Kumar. "Studies on genetic variability, correlation and path analysis in rice". New Botanist 23 (1996): 129-133.

22. Shanmugam A S and S R S Rangsamy. "Genetic diversity for quantitative characters in greengram (Vigna radiate L Wilczek)". Madras Agricultural Journal 69.10 (1982): 631-636.

23. Shanthakumar G., et al. "Studies on genetic variabiliw. correlation and path analysis in rice (Oryza saliva L.) over seasons". Journal of Agricultural Science 11.1 (1998): 67-72.

24. Singh X J K., et al. "Genetic divergence in boro rice”. Oryza 36.1 (1999): 76-77.

25. Steel R C D., et al. "Principles and procedures of statistic. Mc Graw Hill Book Co. Inc., New York (1980): 107-109.

26. Sundaram T and S Palanisamy. "Path analysis in early rice (Oryza saliva L.)" (1994).

27. Surek H., et al. "Correlation and path analysis for yield and yield components in rice in a 8-parent half diallel set of crosses”. Oryza 35.1 (1998): 15-18.

28. Vivekananda P and S Subramniam. "Genetic divergence in rainfed rice”. Oryza 30 (1993): 60-62.

\section{Assets from publication with us}

- Prompt Acknowledgement after receiving the article

- Thorough Double blinded peer review

- Rapid Publication

- Issue of Publication Certificate

- High visibility of your Published work

Website: www.actascientific.com/

Submit Article: www.actascientific.com/submission.php

Email us: editor@actascientific.com

Contact us: +919182824667 